2010s-48

\title{
The Impact of Court Errors on Liability Sharing and Safety Regulation for Environmental/Industrial Accidents
}

\author{
Marcel Boyer, Donatella Porrini
}

\begin{tabular}{c}
\hline Série Scientifique \\
Scientific Series
\end{tabular}

Montréal

Décembre 2010

(C) 2010 Marcel Boyer, Donatella Porrini. Tous droits réservés. All rights reserved. Reproduction partielle permise avec citation du document source, incluant la notice $($ ).

Short sections may be quoted without explicit permission, if full credit, including (C) notice, is given to the source.
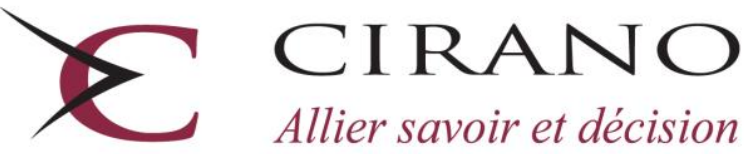

Allier savoir et décision

Centre interuniversitaire de recherche en analyse des organisations 


\section{CIRANO}

Le CIRANO est un organisme sans but lucratif constitué en vertu de la Loi des compagnies du Québec. Le financement de son infrastructure et de ses activités de recherche provient des cotisations de ses organisations-membres, d'une subvention d'infrastructure du Ministère du Développement économique et régional et de la Recherche, de même que des subventions et mandats obtenus par ses équipes de recherche.

CIRANO is a private non-profit organization incorporated under the Québec Companies Act. Its infrastructure and research activities are funded through fees paid by member organizations, an infrastructure grant from the Ministère du Développement économique et régional et de la Recherche, and grants and research mandates obtained by its research teams.

\section{Les partenaires du CIRANO}

Partenaire majeur

Ministère du Développement économique, de l'Innovation et de l'Exportation

\section{Partenaires corporatifs}

Banque de développement du Canada

Banque du Canada

Banque Laurentienne du Canada

Banque Nationale du Canada

Banque Royale du Canada

Banque Scotia

Bell Canada

BMO Groupe financier

Caisse de dépôt et placement du Québec

Fédération des caisses Desjardins du Québec

Financière Sun Life, Québec

Gaz Métro

Hydro-Québec

Industrie Canada

Investissements PSP

Ministère des Finances du Québec

Power Corporation du Canada

Raymond Chabot Grant Thornton

Rio Tinto

State Street Global Advisors

Transat A.T.

Ville de Montréal

\section{Partenaires universitaires}

École Polytechnique de Montréal

HEC Montréal

McGill University

Université Concordia

Université de Montréal

Université de Sherbrooke

Université du Québec

Université du Québec à Montréal

Université Laval

Le CIRANO collabore avec de nombreux centres et chaires de recherche universitaires dont on peut consulter la liste sur son site web.

Les cahiers de la série scientifique (CS) visent à rendre accessibles des résultats de recherche effectuée au CIRANO afin de susciter échanges et commentaires. Ces cahiers sont écrits dans le style des publications scientifiques. Les idées et les opinions émises sont sous l'unique responsabilité des auteurs et ne représentent pas nécessairement les positions du CIRANO ou de ses partenaires.

This paper presents research carried out at CIRANO and aims at encouraging discussion and comment. The observations and viewpoints expressed are the sole responsibility of the authors. They do not necessarily represent positions of CIRANO or its partners. 


\title{
The Impact of Court Errors on Liability Sharing and Safety Regulation for Environmental/Industrial Accidents
}

\author{
Marcel Boyer ${ }^{\dagger}$, Donatella Porrini ${ }^{*}$
}

\begin{abstract}
Résumé
Nous considérons dans le présent document les effets des erreurs judiciaires sur le partage optimal des responsabilités entre entreprises et financiers, comme un instrument de politique environnementale. En utilisant un modèle structurel des interactions entre les entreprises, les institutions financières, les gouvernements et les tribunaux, nous montrons, au moyen de simulations numériques, les distorsions dans le partage de responsabilités entre entreprises et financiers qu'implique la mise en œuvre imparfaite des politiques gouvernementales. Nous considérons en particulier le rôle joué par l'efficacité des tribunaux à éviter les erreurs de type I (condamner une entreprise innocente de manquements à la sécurité) et de type II (ne pas condamner une entreprise coupable de manquements à la sécurité). Nous considérons un contexte où le partage des responsabilités est déjà altéré (par rapport à l'optimum de premier rang), en raison non seulement des difficultés des tribunaux à observer correctement les efforts de prévention des entreprises mais aussi de la présence d'aléa moral et sélection adverse dans les contrats de financement. Il n'y a pas absence de congruence entre les objectifs des entreprises et financiers d'une part et la maximisation du bien-être social d'autre part. Nos résultats indiquent qu'une plus grande efficacité du système judiciaire à éviter les erreurs entraine une hausse des activités de prévention d'accident et donc une baisse de la probabilité d'accident, et permet de réduire (d'augmenter) la part de responsabilité des entreprises (financiers) et de réduire le niveau requis de prévention.
\end{abstract}

Mots clés : Politique environnementale, efficacité des tribunaux, partage de responsabilités, informations incomplètes

\footnotetext{
* We are grateful to participants in the Stony Brook Law and Economics Workshop (Long Island, July 2005), the Annual Meetings of the American Law and Economics Association (New York May 2005 and Princeton May 2010), the Joint Seminar of The Geneva Association and the European Association of Law and Economics (Lecce, June 2007), the Markets and Organizations Seminar of l'École Polytechnique de Paris (Paris, February 2009), the Annual Meeting of the Canadian Law and Economics Association (Toronto, October 2009), and the CESifo Conference in Law and Economics (Munich, May 2010) for their comments on related papers as well as previous versions of this paper. We remain of course solely responsible for the content and shortcomings of this paper.

${ }^{\dagger}$ Bell Canada Emeritus Professor of Industrial Economics, Université de Montréal, Research Associate, Department of Economics, École Polytechnique de Paris and Fellow CIRANO. Email: Marcel.Boyer@cirano.qc.ca † Professore Associato, Facoltà di Economia, Università del Salento
} 


\begin{abstract}
We focus in this paper on the effects of court errors on the optimal sharing of liability between firms and financiers, as an environmental policy instrument. Using a structural model of the interactions between firms, financial institutions, governments and courts we show, through numerical simulations, the distortions in liability sharing between firms and financiers that the imperfect implementation of government policies implies. We consider in particular the role played by the efficiency of the courts in jointly avoiding Type I (finding an innocent firm guilty of inappropriate care) and Type II (finding a guilty firm not guilty of inappropriate care) errors. This role is considered in a context where liability sharing is already distorted (when compared with first best values) due not only to the courts' own imperfect assessment of safety care levels exerted by firms but also to the presence of moral hazard and adverse selection in financial contracting. There is also not congruence of objectives between firms and financiers on the one hand and social welfare maximization on the other. Our results indicate that an increase in the efficiency of court system in avoiding errors raises safety care level, thereby reducing the probability of accident, and allowing the social welfare maximizing government to impose a lower liability [higher] share for firms [financiers] as well as a lower standard level of care.
\end{abstract}

Keywords: Environmental Policy, Court Efficiency, Liability Sharing, Regulation, Incomplete Information.

Codes JEL : D82, G32, K13, K32, Q28 


\section{INTRODUCTION}

The diffusion of industrial and environmental risks has stirred an important debate about the proper instruments to implement public policies toward environmental protection and industrial safety. Two such instruments are the definition of proper care and safety levels and the distribution of responsibilities and liabilities, should an accident occur, among the different actors involved directly or indirectly in risky activities. ${ }^{1}$

Legislators typically impose a liability regime, either a strict one or a negligence based one or both, and a wide range of regulations ${ }^{2}$ relative to environmental and/or industrial risks. The objective is to find the combination of liability rules and safety regulation and standards to be imposed on producers and operators as well as on other stakeholders in order to attain, though the level of care that the latter are incentivised to choose, the socially efficient level of environmental and industrial risks. Achieving the right balance of instruments is a highly complex task. ${ }^{3}$

From an economic perspective, a system of strict or negligence based liability for industrial accidents together with a liability sharing rule among stakeholders can be seen as an instrument to internalise damage and to alleviate the judgment proof problem, which appears when a firm lacks the resources to pay for the damage it has caused. The assignment of liability, a generalization of both compulsory insurance and extended liability provisions under limited liability, ${ }^{4}$ provides potentially liable parties with incentive to require, to induce and/or to exert proper care: an ex post liability system induces ex ante investments in care.

${ }^{1}$ In the recent major oil spill in the Gulf of Mexico, the distribution of liabilities among different stakeholders involved one way or another in the operation, namely BP, Transocean, Haliburton, Cameron International, Anadarko Petroleum and Mitsui to name a few, will likely take years to determine. Some of those partners may even be subject to bankruptcy.

${ }^{2}$ For instance, Trebilcock and Winter (1997) discuss the case of accident in nuclear power production for which the Price-Anderson Act imposes strict liability in addition to a wide range of plant-level regulations by the Nuclear Regulatory Commission. See also Shleifer (2010).

${ }^{3}$ Shavell (1984); Kolstad, Ulen, Johnson (1990); Burrows (1999); Schmitz (2000); Innes (2004).

${ }^{4}$ The connection between ex post liability effects and ex ante prevention behaviour is stressed by the law and economics literature, for instance with respect to the jurisprudence surrounding the CERCLA. See Calabresi (1970); Shavell (1987), Boyer and Laffont (1997), Boyer and Porrini (2001, 2006). 
We wish to illustrate in this paper the incomplete information efficiency distortions (from the first best values obtained under full, albeit imperfect information) in the liability sharing formula and the standard of care. We propose an extended principal agent liability model to analyse the distribution of liability shares among firms and financiers (insurers or bankers). The law and economics literature represents principal agent liability as a framework where rational self interested agents choose their preventive care level under the monitoring activities of a principal. ${ }^{5}$ We widen the traditional framework by adopting the legislator's point of view in determining the liability sharing rule between firms and financiers and the standard of care in order to maximise social welfare, taking into account the asymmetric information (moral hazard and adverse selection) present in financial contracting as well as the existence of court errors in finding a firm guilty or not of negligence.

Hence, we consider the relationships between four actors or stakeholders in the determination of the probability of environmental/industrial accidents: firms, financiers, government and courts. An important specific contribution of this paper is to take a first look at how higher court efficiency in avoiding judicial errors impacts the liability sharing formula and the standard of care as well as the resulting level of care, probability of suing, probability of accident, and probability of conviction. Shleifer (2010) argues that "the ubiquity of regulation is explained not so much by the failure of markets, or by asymmetric information, as by the failure of courts to solve contract and tort disputes cheaply, predictably, and impartially." We will show here that an increase in court efficiency leads to a reduction in the standard of care, which one can interpret as an indicator of regulation.

In the next section, we discuss the implementation of liability sharing among firms and financiers through financial responsibility, lenders' liability provisions and jurisprudence in the American and European systems. In section 3, we discuss the effects of court errors in the context of achieving an efficient environmental policy choice of instruments.

\footnotetext{
${ }^{5}$ See Laffont and Martimort (2001) for the standard presentation and discussion of such frameworks and Polinsky (2003) for a discussion of principal-agent liability. Daughety and Reinganum (2006) proposed to widen the standard law and economics framework by assuming, in reference to product liability, that the market conditions and the tort system interact to affect the decision on care levels.
} 
Section 4 is devoted to modelling the interactions between governments, firms, financiers and courts in the determination of the probability of accident, in a context characterised by moral hazard and adverse selection, an imperfect court system, and the noncongruence of objectives between firms and financiers on the one hand and a social welfare maximizing benevolent government on the other. We present, in Section 5, a simplified example, which incorporates the main characteristics and constraints of the analytically (too) complex interactions between the four stakeholders. We perform, in Section 6, a sensitivity analysis of the impact on the liability sharing formula, on the standard level of care, and on the levels of the other endogenous variables (exerted care level, probability of accident, probability of suing, and probability of conviction) of variations in the efficiency of the court system and of other parameters of interest such as the profitability of the firm's project or activities, the cost of care activities, the efficiency of care in reducing the probability of accident, the cost of suing, and the social cost of public funds. We conclude in Section 7.

\section{LIABILITY SHARING AMONG FIRMS AND FINANCIERS: US AND EU}

Civil liability for environmental damages has become a relevant instrument of environmental policy. The issue of environmental liability emerged some thirty years ago with several important pollution cases unravelling and, at the same time, an increased number of small enterprises entering risky sectors. ${ }^{6}$ The US Congress enacted the Comprehensive Environmental Response, Compensation and Liability Act (CERCLA $1980,1996)$ to bring quick relief and remedy action after an accident, to cope with the "decontamination" of polluted sites, and to recover the clean-up and compensation costs from the liable parties. The liable parties include by law the past and present owners and the operators of the affected sites, the generators of dangerous materials, and the carriers of such material. The system is characterised by retroactivity of liabilities and involvement of many potentially responsible parties (PRP). ${ }^{7}$

In Europe, the Directive on Environmental Liability with Regard to the Prevention and Remedying of Environmental Damage puts emphasis on the 'polluter pays principle':

${ }^{6}$ See Ringleb and Wiggins (1990).

${ }^{7}$ Under CERCLA, liability is strict, joint and several. 
"The fundamental principle of this Directive should therefore be that an operator whose activity has caused the environmental damage or the imminent threat of such damage is to be held financially liable, in order to induce operators to adopt measures and develop practices to minimise the risks of environmental damage so that their exposure to financial liabilities is reduced." ${ }^{8}$ Article 14 of the Directive states: "Member States shall take measures to encourage the development of financial security instruments and markets by the appropriate economic and financial operators, including financial mechanisms in case of insolvency, with the aim of enabling operators to use financial guarantees to cover their responsibilities under this Directive".

From a law and economics analysis viewpoint, these ex post liability systems could provide firms with optimal incentives to undertake ex ante safety measures and, in this way, internalise the full costs associated with accidents. However, environmental damages are often very large and it is not uncommon that they exceed the resources of the responsible firm. Liability may trigger the bankruptcy of the firm: the so called judgment proof problem, ${ }^{9}$ under which residual damages remain externalised and uncompensated, thereby reducing ex ante incentives and the exerted level of care below the optimal level. One way by which environmental laws aim to remedy the judgment proof problem is to extend liability for residual damages to parties that have contractual relationships with the firm that causes the damages.

In America, in spite of a secured interest exemption clause protecting financial institutions holding instruments of ownership on firms' assets, the courts have repeatedly considered secured lenders as owners or operators, when their involvement in the firm, before and/or after the accident and/or the foreclosure, exceeded the level warranted to secure their interest. ${ }^{10}$

\footnotetext{
${ }^{8}$ Directive 2004/35/CE of the European Parliament and of the Council of 21 April 2004 on environmental liability with regard to the prevention and remedying of environmental damage, Official Journal of the European Union, L143/56, 30/4/04. See also Directive 2008/99/EC on criminal sanctions.

${ }^{9}$ See Shavell (1986).

${ }^{10}$ See for instance the following major court cases: US v. Mirabile (15, Environmental Law Reports 20, 994 (E.D. Pa. 1985)); US v. Maryland Bank and Trust (632 F. Su 573 (d. Md. 1986)); US v. Fleet Factors Corp. (901 F. 2d 1550 (11th Cir. 1990), cert. Denied 498 US 1046 (1991)); US v. Pesses (1998 WL 937235 (W.D. Pa. May 6, 1998); New York v. HSBC Bank USA (Docket No. 07-CV-3160, Dec. 22,
} 
Extending liability could, under certain conditions, be efficient given the possibility of the parties, through their contractual relationship, to restore the firm's incentive to take the "optimal" level of care. Under full information, the extension of ex post liability to a firm's deep pocket financiers is efficient because the latter will induce the firms to adopt adequate prevention measures. The socially optimal level of prevention is then attained and victims are appropriately compensated if damage does occur. Reality, however, lags woefully behind such optimal conditions, as financiers have only incomplete information about the preventive measures adopted by the firms they finance. Thus, financial institutions cannot fully link the terms of the financial contract with the desired level of prevention. In such contexts, Boyer and Laffont (1997) show that partial extended liability may be necessary to obtain the second best levels of financing and prevention.

Lenders' liability, insurance policies, and financial responsibility ${ }^{11}$ are instruments through which responsibility is extended and therefore shared between the firms and their financial partners. Clearly, financiers will transfer their expected liability cost to firms' financing conditions, which impact positively the firm's incentive to exert care.

\section{LIABILITY SHARING AND COURT ERRORS}

The economic analysis of the efficiency of lender's liability and financial responsibility leads in the direction of characterizing the proper sharing of liability between firms and financiers, representing more generally the firms' partners. In our model, we give financiers the right to be protected from negligent firms, even under the basic strict liability rule: the financier may decide to sue the firm for negligence (that is, for having exerted a level of care lower than the standard level fixed by the government) and if it

2006 Consent Decree). The critical level of involvement was lowered over time and lender's liability turned out to be more common than expected or intended. See Boyer and Laffont (1996) and Boyer and Porrini (2004) for an economic analysis of lenders' liability cases and Gracer and Leas (2008) for a legal analysis.

${ }^{11}$ Financial responsibility may be proven by different means such as letters of credit and surety bonds; cash accounts and certificates of deposit; self-insurance and corporate guarantee (Directives 2004/35/CE and 2008/99/CE). In the case of hazardous waste, the Resource Conservation and Recovery Act (RCRA) and the Comprehensive Environmental Response Act (CERCLA) provide for the companies that "treat, store, dispose, or transport hazardous waste" to demonstrate adequate financial guarantees for third-party damage, through an insurance or a proof of financial coverage. See also the Oil Pollution Act (33 USC \$2716), the Safe Drinking Water Act (SDWA), the Outer Continental Shelf Lands Act (OCSLA), and the Surface Mining Control and Reclamation Act (SMCRA). See Boyd (2001) for an assessment of financial assurance in the US. 
does, it will fall on the courts to verify whether the firm did abide by the government determined standard of care or not. In this way, the financial institutions have the possibility to recover part of the payment they already expensed (under strict liability) for the environmental damage caused by negligent firms.

Financial institutions then have a right to contribution, defined as the "tortfeasor's right to collect from others responsible for the same tort after the tortfeasor has paid more than his or her proportionate share, the shares being determined as a percentage of fault" (CERCLA $\S 107,113){ }^{12}$ This justifies in our model the possibility for the financial institutions to bring suit against their client firms.

However, courts may make errors that affect incentives for care. Tullock (1980), citing American and British studies on disagreements between different levels of courts, between juries and judges, and between different juries in experimental settings, estimates the probability of court errors to be at least 13\%. Tullock (1994) writes: "Even the best functioning legal system will not function without committing errors. Court errors can be about questions of law and questions of fact." Marco (2006) considers court errors in the context of patents, which are uncertain property rights, and estimates probabilities of court errors using stock market reactions to patent litigation decisions: "While court errors are inherently unobservable, the estimation quantifies beliefs about patent validity and court errors in a Bayesian context by relying on observable win rates and stock market reactions ... [T] he underlying beliefs about validity average from 0.55 to 0.70 for litigated patents ... Type I errors (finding a valid patent invalid) occur with an estimated probability of 0.20 to 0.25 ... Type II errors (finding an invalid patent valid) varies more broadly, from near zero probability to as high as 0.40 ".

Both errors of Type I (finding an innocent firm guilty of negligence) and errors of Type II (finding a negligent firm not guilty of negligence) are detrimental to care. Acquittals of guilty parties reduce the benefits of care as they lower the probability of conviction, while convictions of innocents reduce the relative benefits of exerting care. As expressed by Kaplow (1994): "Accuracy is relevant in controlling behaviour because increasing

\footnotetext{
${ }^{12}$ US Supreme Court 02-1192, Cooper Industries v. Aviall Services, December 13, 2004; US Supreme Court 06-62, US v. Atlantic Research Corporation, June 11, 2007.
} 
accuracy, like increasing the level of sanctions or enforcement effort, is a method of increasing deterrence." Greater accuracy increases both the likelihood that the guilty are sanctioned and the likelihood that the truly innocent will not be sanctioned. ${ }^{13}$

Bhole (2007) and Bhole and Wagner (2008) discuss different ways to induce a given care level through due care standards and penalty multipliers when courts can make errors. Bisso and Choi (2008) observe that a deep pocket principal is often held liable and responsible for harm caused by a judgment proof agent's negligence (vicarious liability) and analyse in such a context the relationships between the principal and the agent when a court determines whether the agent was negligent or not with some level of error. They show that "reducing the error of declaring the agent not negligent even when he was (prodefendant or type II error) is better than reducing the error of declaring the agent negligent even when he was not (pro-plaintiff or type I error)." Intuitively, there is a mean preserving spread between the two in such a way that the agent is more sensitive to a reduction of the former. ${ }^{14}$

Limited observability of care is equivalent to having both observable and unobservable care. Bhole and Wagner (2008) consider multidimensional care, as do Hutchinson and Van't Veld (2005). Dari-Mattiaci and De Geest (2005) and De Geest and Dari-Mattiaci (2007) consider both probability reducing care (self protection) and loss reducing care (self insurance) in the presence of judgment proofness. In their (2007) paper, they write: "This difference bears on the shape of the insolvent injurer's cost function under a liability rule and hence on the way regulation impacts the injurer's behaviour." ${ }^{\prime 15}$ In the model we develop in the present paper, firms face ex post strict liability if an accident occurs and ex ante regulation through the standard level of care. ${ }^{16}$

\footnotetext{
${ }^{13}$ See Png (1987) and Polinsky and Shavell (2007). Of course, this does not imply that reliability should be $100 \%$. Reliability involves benefits but also costs. We do not address here the determination of a socially optimal reliability level which would need a proper consideration of both benefits and costs of such court reliability.

${ }^{14}$ See Rothchild and Stiglitz (1970) and Boyer and Dionne (1983) for discussions of mean preserving spreads.

${ }^{15}$ This suggests the existence of a mean preserving spread analysis. See footnote 14 above.

${ }^{16}$ An anonymous referee suggested that further research on this aspect is warranted, because the environmental arena is characterised in a fundamental way by both ex ante regulation of observable care
} 
Landeo, Nitikin and Baker (2007) develop a strategic model of liability and litigation in the presence of court errors in determining punitive damages, with the endogenous choice of level of care and likelihood of suing. They consider a mixed-strategy perfect Bayesian equilibrium under low court errors: "In this equilibrium, some defendants choose to be grossly negligent; some cases are filed; and some lawsuits are dropped, some are resolved out of court, and some go to trial. We find that court errors in the size of the award ... reduce the deterrence effect of punitive damages." ${ }^{, 17}$

Boyer, Lewis and Liu (2000) analyse a two stage asymmetric information game where the level of enforcement effort and the level of negligence are simultaneously determined (in stage 2) in reaction to the levels of sanction and due care standards (stage 1) optimally chosen in anticipation of the second stage interactions between law enforcers and care providers. They show that "the strategic interaction between care providers and law enforcers determines the degree of efficiency achieved by the standards ... [T] he setting of standards may effectively substitute for the setting of fines when penalties for violation are fixed ... [M]aximal fines may be welfare reducing when standards are set optimally."

\section{THE MODEL}

The probability of an environmental or industrial accident depends in a real sense on the actions of four major actors or stakeholders, namely government, financiers, firms and courts, interacting under information constraints, legal constraints, and bounded rationality constraints. It therefore results from the interactions between those actors, whose interests and objectives will not in general be congruent. ${ }^{18}$ The behaviour of the four actors is subject to significant limitations arising from the limited liability of firms, the limited capacity of governments to intervene, the limited power of the court system to search and find all the facts relevant to a judgment, and more generally the asymmetric

and ex post liability that is designed to align private unobservable and overall care rates with socially optimal rates.

${ }^{17}$ More precisely, they consider the universal divinity refinement of mixed-strategy perfect Bayesian equilibrium. For more on divinity refinements in mixed-strategy perfect Bayesian Equilibria, see Boyer, Laffont, Mahenc, and Moreaux (1991, 1994, 1995).

${ }^{18}$ The model we develop here is based on Boyer and Porrini $(2006,2008)$ with an important change: the court assessment of liability in litigation cases is imperfect. 
information between the actors. We analyse the interactions between the above four stakeholders as a three stage game and we characterise subgame perfect equilibria.

We consider in this article an extended, hence shared liability framework. As discussed above, such a framework is often justified on the grounds that the agent may end up having insufficient assets to pay for the harm caused (judgment proof), hence having suboptimal incentive to exert care when performing a potentially hazardous task. From the viewpoint of environmental policies, extending liability to a deep pocket partner of the firm can reduce the probability of accident because the partner, acting as principal, is then induced to influence the agent's care performance through better monitoring and stronger incentives. The intent was explicit in the court judgment in the Fleet Factors case:

Under the standard we adopt today, a secured creditor may incur ... liability without being an operator, by participating in the financial management of a facility to a degree indicating a capacity to influence the corporation's treatment of hazardous wastes. It is not necessary for the secured creditor to actually involve itself in the day to day operations of the facility in order to be liable - although such conduct will certainly lead to the loss of the protection of the statutory [secured creditor] exemption. Nor is it necessary for the secured creditor to participate in management decisions relating to hazardous waste. Rather, a secured creditor will be liable, if its involvement with the management of the facility is sufficiently broad to support the inference that it could affect hazardous waste disposal decisions if it so chose. ${ }^{19}$

In our model, the partner of the firm, here the banker or insurer as the financial partner enabling the firm to pursue its business operations, will be allowed to sue the firm for negligence when the latter causes an accident. ${ }^{20}$ We consider in such a context the effects

\footnotetext{
19 Journal of Environmental Law 4[1], p. 148. See Shavell (1982) and Demougin and Fluet (2008). See also Boyer and Laffont (1996) and Boyer and Porrini (2004) for a discussion of the decision in the Fleet Factor case, in which the judge expands on the likelihood of financial partners to be better principals than government officials.

${ }^{20}$ Clearly, this is one channel by which the financier can influence the firm, but there may be others too. More generally, the principal could sue other PRP, including the government as illustrated for instance the US Supreme Court case US v. Atlantic Research Corp. and the US Supreme Court case Cooper
} 
on the environmental policies (the liability sharing factor and the standard level of care) of the efficiency of courts in avoiding judicial errors, as well as the effects of other parameters we will introduce and discuss below.

In stage 1 , the government chooses the strict liability sharing rule $\alpha$, by which the firm is strictly liable for a proportion $\alpha$ of the cost of an accident while the financier is strictly liable for a proportion $(1-\alpha)$ of that cost, and the standard level of care $s$ to maximise a social welfare function we will characterise below.

In stage 2, given the values of $\alpha$ and $s$ chosen by the government, a firm and a bank enter into a financial contract. We assume that the firm needs a loan of $K$ from the bank to operate a risky project: the project generates net benefits (profits) $\pi_{l}$ with probability $\mu$ and $\pi_{2}$ with probability $1-\mu$, with $\pi_{2}>\pi_{1}$. The realised level of profit is typically private information of the firm. The firm must repay the loan plus interest and failing to do so triggers bankruptcy procedures. In order to concentrate on the judgment proof problem, we assume that, in the no accident case, the firm always repays the bank and that, in the accident case, the bank has priority on other claimants on the firm resources. Hence, the loan itself, absent consideration of the possibility of an accident, is basically riskless. $^{21}$

The amount to be repaid by the firm to the financier depends neither on the firm's exerted level of care nor on the firm's profits, as those variables are unobservable; it is rather composed of two terms: $Z Z=(1+r) K+(1-\alpha) p(s) L$, where $r$ is the (exogenous) competitive riskless interest rate, and $(1-\alpha) p(s) L$ is a 'liability premium', where $p(\cdot)$ is the probability of accident and $L$ is the level of damage if an accident occurs. This

Industries v. Aviall Services Inc. Referenced in footnote 12 above. In cases of suretyship, the firm and its partners (indemnitors) are usually jointly and severally liable to reimburse the surety (the banker or insurer for instance) who can sue therefore its client firm and possibly other indemnitors to recover expenses or losses incurred. This is the kind of framework we model here. See Bachrach (1998) for more on suretyships. Among legal cases of interest in this matter, one may cite the following: Fidelity and Deposit Co. Of Maryland v. Bristol Steel \& Iron Works Inc., 722 F.2d 1160 (4th Cir. 1983);

Transamerica Ins. Co. V. Bloomfield, 401 F.2d 357 (6th Cir. 1968); General Accident Ins. Co. of America v. Merritt-Meridian Constr. Corp., 975 F.Supp. 511 (S.D.N.Y. 1997).

${ }^{21}$ This is clearly a strong assumption which could be relaxed at the cost of more complexity. In the present case and for our purpose, this additional complexity would not bring significant additional insights. 
liability premium is based on the observed legal level of care $s$ and not on the level of exerted care $q$.

The firm and the financier choose their respective decision variables at this stage: we assume that the financier first announces and commits to its choice of probability of suing $v^{22}$ at cost $C(v)$, before the firm, observing $v$, chooses a level of care activities $q$ at cost $Q(q)$, which determines the true probability $p(q)$ of an accident [assumed to be decreasing and convex: $\left.p^{\prime}(q)<0, p^{\prime \prime}(q)>0\right]$. We characterise the resulting Stackelberg Equilibrium in $(v, q)$.

Two different types of liability are present in our model: first, a strict liability rule that governs the share of costs that falls respectively on the financiers and the firms; second, a liability for negligence under which the financial partner can sue the firm to recover its share of the costs of the accident if the firm is found by the court to have exerted a level of care below the standard level determined by the government. It is through this capacity to sue that financiers appear as limited and constrained principals and the firms as agents.

In stage 3, all actors observe whether an accident occurs or not (profits remain unobserved). If no accident occurs, the firm realises the profits of the project and repays the bank. If an accident occurs, the strict liability rule applies: the financier is responsible for covering (1- $\alpha) L$ and the firm for covering $\alpha L$ of the cost $L$ of the accident. ${ }^{23}$ The financier sues the firm with probability $v$.

If the financier indeed sues the firm, then the latter incurs legal defence cost $C_{F}$ and the case is litigated in court. The court suffers from asymmetric information, just as the government and the financier do, but is assumed to have superior (subpoena) power to investigate the safety behaviour of the firm. The court does not observe the firm's profit level. If the firm is declared guilty of negligence, either it reimburses the observed cost incurred by the bank (1- $\alpha) L$ or the latter seizes its assets. Hence, the court does not need

\footnotetext{
${ }^{22}$ We assume that the financier commits to its choice of $v$. One may think that if the financier builds up a suing capacity, for instance through a specific inside group of lawyers, then it is bound to let them work and therefore sue firms with the implied probability $v$.

${ }^{23}$ We consider the loss $L$ as fixed and therefore independent of care. We make that assumption to concentrate on the probability of accident.
} 
to determine the level of compensation. The court ponders the evidence and decides on whether there is breach of contract, that is, whether $q$ is less than $s$ or not.

We represent the court decision making process under incomplete information as follows: the firm is found guilty of insufficient care with a reduced form probability $\hat{P}(q, s)=f(q, s, \gamma) P(q, s)$, where the function $P(q, s)$ is assumed to be always positive (hence, both Type I and Type II errors are possible), but decreasing and convex in $q$ and increasing in $s$ [namely $P_{q}(q, s)<0, P_{q q}(q, s)>0$ and $P_{s}(q, s)>0$ ]. The parameter $\gamma$ in the function $f(q, s, \gamma)$ represents, as discussed below, the efficiency of the court in avoiding those errors: a larger $\gamma$ will imply a lower probability of both Type I and Type II errors. $^{24}$

If convicted of negligence, the firm makes the additional payment $(1-\alpha) L$ if possible and otherwise goes bankrupt, in which case the financier seizes the firm's net assets, equal in value to $\max \left\{0, \pi_{1}-\alpha L-Z Z-Q(q)-C_{F}\right\}$.

The determination of endogenous variables or decisions $(\alpha, s, v$ and $q)$ is obtained recursively.

The third stage: At this stage all variables have been determined, leading eventually to a resulting state of the world. Hence, given previously determined values of $\alpha, s, v$, and $q$, we obtain the expected values of the financier's profit and the firm's profit.

The total expected profit of the financier $E \Pi_{I}$ can be written as follows:

\footnotetext{
${ }^{24}$ The court efficiency parameter $\gamma$ affects similarly both Type I and Type II errors, whose probabilities move in tandem as $\gamma$ changes. Moreover, changes in this efficiency parameter are assumed to be costless, as it is the case for changes in the other parameters in the model. Our objective here is to conduct a standard (except for the complexity of the analysis) comparative statics analysis. However, as an anonymous referee suggested, it would be of interest to look also at a model with two (costly) court efficiency parameters, one for Type I errors and one for Type II errors, to conduct an 'optimal court efficiency' analysis. This would be a nice topic for future research, with Polinsky and Shavell (2007) and Bisso and Choi (2008) as starting points. Similarly, increased efficiency through reduction of evidentiary uncertainty could be considered, with Fluet (2010) as a starting point.
} 


$$
\begin{aligned}
& E \Pi_{I}\left(v, q, \alpha, s ; K, r, \pi_{1}, \pi_{2}, \mu\right)=Z Z-C(v) \\
& -p(q)[(1-v)+v(1-\hat{P}(q, s))](1-\alpha) L \\
& -p(q) v \hat{P}(q, s)(1-\mu)[0] \\
& \quad-p(q) v \hat{P}(q, s) \mu\left[(1-\alpha) L-\max \left\{0, \pi_{1}-\alpha L-Z Z-Q(q)-C_{F}\right\}\right]
\end{aligned}
$$

The first term $Z Z-C(v)$ is the profit, gross of loan $K$, in the absence of an accident. If an accident occurs, then the financier will incur the full cost of its liability share, namely $(1-\alpha) L$, in two situations: first, if it does not sue the firm and second, if the firm is found not guilty by the court (second term: $-p(q)[(1-v)+v(1-\hat{P}(q, s))](1-\alpha) L)$; if the financier sues the firm and the firm is found guilty, then the financier can recover its full share of the damages when the firm has realised the high level of profit, in which case the financier's cost is zero (third term: $-p(q) \nu \hat{P}(q, s)(1-\mu)[0]$, as we assume for simplicity that if profit is high, that is, if the project is ex post very valuable, the firm can pay the full amount of damages; finally, if the financier sues the firm and the firm is found guilty, then it may be able to recover part of its (strict liability) payments if the firm has realised the low level of profit, in which case either the firm can pay part of the financier's costs or not, depending on whether $\pi_{1}-\alpha L-Z Z-Q(q)-C_{F}$ is positive or not, hence the fourth term: $-p(q) v \hat{P}(q, s) \mu\left[(1-\alpha) L-\max \left\{0, \pi_{1}-\alpha L-Z Z-Q(q)-C_{F}\right\}\right]$.

The total expected profit of the firm $E \Pi_{F}$ can be written as follows, where

$$
\begin{aligned}
& E \pi=\mu \pi_{1}+(1-\mu) \pi_{2}: \\
& \begin{aligned}
& E \Pi_{F}\left(v, q, \alpha, s ; K, r, \pi_{1}, \pi_{2}, \mu\right)=E \pi-Q(q)-Z Z \\
&-p(q)(1-v)[\left.(1-\mu) \alpha L+\mu \min \left\{\alpha L, \pi_{1}-Q(q)-Z Z\right\}\right] \\
&-p(q) v(1-\hat{P}(q, s))\left[(1-\mu)\left(\alpha L+C_{F}\right)+\mu \min \left\{\alpha L+C_{F}, \pi_{1}-Q(q)-C_{F}-Z Z\right\}\right] \\
& \quad-p(q) v \hat{P}(q, s)\left[(1-\mu)\left(L+C_{F}\right)+\mu \max \left\{0, \pi_{1}-Q(q)-C_{F}-Z Z\right\}\right]
\end{aligned}
\end{aligned}
$$

In light of our interpretation of the different terms of the expected profit of the financier, each term of the above expression is self explanatory. 
The second stage: At this stage, the values of $\alpha$ and $s$ have been determined and the firm and the financier make their respective decisions. The firm chooses $q$ satisfying

$\frac{\partial E \Pi_{F}}{\partial q}=0$

giving rise to the best reply function $q\left(v \mid \alpha, s ; \gamma, K, r, \pi_{1}, \pi_{2}, \mu, L, C_{F}, C_{B}\right)$ to the choice of $v$ made by the financier, given $\alpha$ and $s$ set by the government. Knowing this best reply function of the firm, the financier chooses $v$ satisfying

$\frac{d E \Pi_{B}}{d v}=0$

taking full account of the best reply function of the firm. The solution to these two conditions gives us the second stage equilibrium values, which can be expressed as functions of the government determined variables $\alpha$ and $s$, namely:

$v^{*}\left(\alpha, s ; \gamma, K, r, \pi_{1}, \pi_{2}, \mu, L, C_{F}, C_{B}\right)$

$q^{*}\left(\alpha, s ; \gamma, K, r, \pi_{1}, \pi_{2}, \mu, L, C_{F}, C_{B}\right)$.

\section{The first stage}

We consider, again to simplify the presentation but without loss of generality, that the determination of the liability sharing formula involves a "political economy" $\operatorname{cost} A(\alpha)$ if the government wants to implement a formula away from the most acceptable formula from a social or political standpoint (assumed below to correspond to an equal liability sharing: $\alpha=0.5){ }^{25}$

The social welfare function $\operatorname{SWF}(\alpha, s)$ is given by the following, where $W$ is the social value of the firm's project or activities and $\lambda$ is the social cost of public funds representing the cost of government financing either through taxation or public debt:

\footnotetext{
${ }^{25}$ This assumption will make the interpretation of the chosen $\alpha$ easier by determining a reference point
} $\alpha=50 \%$. It plays no other role. 


$$
\begin{aligned}
& \operatorname{SWF}(\alpha, s)=\left[W-p\left(q^{*}\right) L-Q\left(q^{*}\right)-C\left(v^{*}\right)-A(\alpha)\right] \\
& -\lambda p\left(q^{*}\right)\left(1-v^{*}\right) \mu \max \left\{0, \alpha L-\left(\pi_{1}-Z Z-Q\left(q^{*}\right)\right)\right\} \\
& -\lambda p\left(q^{*}\right) v^{*}\left(1-\hat{P}\left(q^{*}, s\right)\right) \mu \max \left\{0, \alpha L-\left(\pi_{1}-Z Z-C_{F}-Q\left(q^{*}\right)\right)\right\} \\
& -\lambda p\left(q^{*}\right) v^{*} \hat{P}\left(q^{*}, s\right) \mu \max \left\{0, \alpha L-\max \left\{0, \pi_{1}-Z Z-C_{F}-Q\left(q^{*}\right)\right\}\right\}
\end{aligned}
$$

The first term of the $S W F$ function, $\left[W-p\left(q^{*}\right) L-Q\left(q^{*}\right)-C\left(v^{*}\right)-A(\alpha)\right]$, is simply the net value of the firm/project absent an accident: the social value $W$ minus the expected cost of an accident, the cost of care, the cost of maintaining the legal suing capacity, and the political economy cost of moving away from the most acceptable liability sharing formula.

The second term, namely $-\lambda p\left(q^{*}\right)\left(1-v^{*}\right) \mu \max \left\{0, \alpha L-\left(\pi_{1}-Z Z-Q\left(q^{*}\right)\right)\right\}$, represents in expected terms the social cost of payments by the government if an accident occurs and the financier is not suing the firm. The firm may be unable to pay its own share of the damages, in which case the government must one way or another pay for the remaining damages, clean-up costs or compensation costs.

The third term, namely $-\lambda p\left(q^{*}\right) v^{*}\left(1-\hat{P}\left(q^{*}, s\right)\right) \mu \max \left\{0, \alpha L-\left(\pi_{1}-Z Z-C_{F}-Q\left(q^{*}\right)\right)\right\}$, represents in expected terms the social cost of payments by the government if an accident occurs, the financier is suing the firm (the firm then suffers a legal defence cost $C_{F}$ ), and the firm is found not guilty. The firm may again be unable to pay its share of the damages of the accident.

Finally, the fourth term, $-\lambda p\left(q^{*}\right) v^{*} \hat{P}\left(q^{*}, s\right) \mu \max \left\{0, \alpha L-\max \left\{0, \pi_{1}-Z Z-C_{F}-Q\left(q^{*}\right)\right\}\right\}$, represents in expected terms the social cost of disbursements by the government if an accident occurs, the financier is suing the firm, and the firm is found guilty of negligence. The firm may once again be unable to pay the full damages of the accident. To understand the form of this last term, one must realise that the government will be a payer only if the firm cannot repay its own share of the damages, in which case the firm cannot reimburse the financier and the government will pay the residual value 
$\alpha L-\left\{\pi_{1}-Z Z-C_{F}-Q\left(q^{*}\right)\right\}$. However, if the firm can reimburse a part of the financier's cost when found guilty of negligence, that is $\alpha L-\max \left\{0, \pi_{1}-Z Z-C_{F}-Q\left(q^{*}\right)\right\}<0$, then the government would pay nothing under the rule of strict liability of the firm and the financier.

The benevolent government maximises this $S W F$ function with respect to $\alpha$ and $s$, considering the social cost of public funds and the effect of its decision on the choice of $v$ and $q$ in the second stage and the resulting probability of accident, expected damages, the court efficiency in avoiding errors, and the total costs of realizing the project, that is, of allowing the firm to operate.

Clearly, the general solution of such a program and the full characterization of the three stage equilibrium is a formidable task. Rather than deriving such a general characterization, which at best will be seriously restricted by a set of conditional statements, we will consider a simplified example, which represents or includes the relevant characteristics of the problem at hand.

\section{A SIMPLIFIED EXAMPLE}

We consider the following functions that satisfy the general characteristics of the functions we introduced above.

$$
\begin{aligned}
& p(q) \equiv p_{0}+\left(p_{M}-p_{0}\right)\left(1-e^{-\eta q}\right) \begin{cases}=p_{0} & \text { if } q=0 \\
\rightarrow p_{M}>0 & \text { if } q \text { becomes very large }\end{cases} \\
& \hat{P}(q, s) \equiv\left(-\gamma q^{2}+\gamma s q+1\right) e^{-\delta(q / s)} \\
& \begin{cases}=1, & \text { if } q=0 \\
=e^{-\delta}, & \text { if } q=s(\hat{P}(s, s)=0.5 \text { if } \delta=\ln 2) \\
\rightarrow 0, & \text { as } q \text { becomes very large }\end{cases}
\end{aligned}
$$

where $\left(-\gamma q^{2}+\gamma s q+1\right)$ equals 1 if either $\gamma=0$ or $q=s$, is increasing with $\gamma$ if $q<s$, and is decreasing with $\gamma$ if $q>s$. Hence as $\gamma$ increases, the probability of finding the firm 
guilty increases if $q<s$, hence reducing Type II errors, and decreases if $q>s$, hence reducing Type I errors.

$Q(q) \equiv z q^{b}$, where $b>1$ and $z$ is a positive parameter.

$C(v) \equiv B v^{n}$

$$
A(\alpha) \equiv A(\alpha-0.5)^{a}
$$

We consider the following base case parameter values: $\pi_{1}=1000, \pi_{2}=5000, \mu=0.2$,

$K=75, r=0.10, p_{0}=0.4, p_{M}=0.05, \delta=\ln (2), z=10, b=1.2, L=4000, \eta=0.2$,

$C_{F}=0, B=1, n=2, \lambda=0.3, A=25, a=2$, and $\gamma=0$.

Given those values, we obtain the following first best solution: ${ }^{26}$

$\alpha_{F B}=0.5, q_{F B}=s=13.17, p\left(q_{F B}\right)=0.075$

and the following asymmetric information solution, which is our base case scenario, from which sensitivity analysis can be performed.

\section{$\underline{\text { Base Case }}$}

Table 1: Base case scenario

\begin{tabular}{|c|c|c|c|c|c|}
\hline$\alpha$ & $s$ & $v$ & $q$ & $p(q)$ & $\hat{P}(q, s)$ \\
\hline $\mathbf{0 . 3 7}$ & $\mathbf{1 7 . 3 3 6}$ & $\mathbf{0 . 8 9 5}$ & $\mathbf{1 1 . 9 0 2}$ & $\mathbf{0 . 0 8 2}$ & $\mathbf{0 . 6 2 1}$ \\
\hline
\end{tabular}

Hence, with asymmetric information, we have $\alpha<\alpha_{F B}$, that is, the liability share of the firm is lower than in the first best (complete, although imperfect information) solution.

${ }^{26}$ All numerical results in this section were obtained through MATLAB programming. We are grateful to Peuo Tuon of CIRANO for her assistance in this matter. 
Moreover, $q<q_{F B}=s$ and $p(q)>p\left(q_{F B}\right)$, that is, the firm exerts less care in preventing accidents and therefore the probability of an accident is larger than under first best conditions.

We consider next the impact on the first best and second best liability sharing $\alpha$, standard of care $s$, probability of suing $v$, exerted care level $q$, probability of accident $p(q)$, and probability of conviction if sued $\hat{P}(q, s)$ of changes in the court efficiency $(\gamma)$ in avoiding errors, the profitability of the firm's project or activities $(\mu)$, the cost $(z)$ of care activities, the efficiency $(\eta)$ of care in reducing the probability of accident, the cost of suing ( $B)$, and the social cost of public funds $(\lambda)$.

Sensitivity to changes in the efficiency of the court system

The parameters are the same as in the Base Case except for the parameter representing the efficiency of the court system to avoid errors of Type I and II, namely $\gamma \in[0,0.009]$. We obtain the following:

Table 2: variable $\gamma$ (efficiency of the court system)

\begin{tabular}{|c|c|c|c|c|c|c|}
\hline$\gamma$ & $\alpha$ & $s$ & $v$ & $q$ & $p(q)$ & $\hat{P}(q, s)$ \\
\hline $\mathbf{0 . 0 0 0}$ & $\mathbf{0 . 3 7 4}$ & $\mathbf{1 7 . 3 3 6}$ & $\mathbf{0 . 8 9 4}$ & $\mathbf{1 1 . 9 0 0}$ & $\mathbf{0 . 0 8 2}$ & $\mathbf{0 , 6 2 1}$ \\
\hline 0.002 & 0.341 & 14.243 & 0.892 & 12.314 & 0.080 & 0,575 \\
\hline 0.003 & 0.304 & 13.246 & 0.891 & 12.480 & 0.079 & 0,535 \\
\hline 0.004 & 0.281 & 12.361 & 0.888 & 12.602 & 0.078 & 0,487 \\
\hline 0.005 & 0.265 & 11.644 & 0.883 & 12.693 & 0.078 & 0,438 \\
\hline 0.006 & 0.249 & 11.107 & 0.877 & 12.775 & 0.077 & 0,393 \\
\hline 0.007 & 0.235 & 10.673 & 0.871 & 12.842 & 0.077 & 0,350 \\
\hline 0.008 & 0.223 & 10.331 & 0.864 & 12.903 & 0.077 & 0,309 \\
\hline 0.009 & 0.211 & 10.063 & 0.856 & 12.961 & 0.076 & 0,271 \\
\hline
\end{tabular}


As parameter $\gamma$ increases, the efficiency of the court system in avoiding errors of Type I and II increases: as $\gamma$ increases, the probability of conviction $\hat{P}(q, s)$ increases if $q<s$, that is, when insufficient care is exerted by the firm, and decreases if $q>s$, that is, when more than sufficient care is exerted.

An increase in the efficiency of the court system generates the following changes in endogenous variables: a reduced liability for the firm and a reduced standard of care (reduced safety regulation); a decrease in probability of suing (reduction in monitoring); an increase in the level of care exerted by the firm, from below the standard level to above that value; a corresponding reduction in the probability of accident; ${ }^{27}$ and a reduction in the probability of conviction if the firm is sued. The reduction in the probability of conviction blends different factors, namely the higher efficiency of the court system, the reduction in the standard of care, and the increase in the level of care exerted.

From the results reported in Table 2, we can say that the efficiency of the court system to avoid errors of both Type I and Type II improves the efficiency of liability sharing as an environmental policy instrument: an increase in $\gamma$ generates a decrease in the probability of accident $p(q))$ resulting from the new liability sharing factor, the new safety regulation level, and the new decisions by financiers and firms.

Two observations of the impact of an increase in the efficiency of the court system deserve some comments. First, as $\gamma$ increases, firms can exert (when $\gamma \geq 0.004$ in this simulation) an "excessive" level of care $q$ as compared to the due care level $s$ chosen by the government. Second, this increase in $\gamma$ allows the government to reduce the liability share of firms and the transfer of a larger liability share to financiers (bankers or insurers).

The first effect suggests that the increased efficiency of the court system generates stronger incentives for firms to exert more care, eventually surpassing the due care

\footnotetext{
${ }^{27}$ The probability decreases steadily even if some values in Table 2 are the same due to rounding values.
} 
level. ${ }^{28}$ Moreover, this increased efficiency of the court system means that firms, which may also suffer from the fact that their chosen care level is difficult to observe by outsiders, would indeed increase their level of care if it can be recognised with more accuracy by the courts, if and when an accident occurs and the firm is sued by its financial partner.

We observe in reality many forms of self regulation (like some cases of green certification) that show an effort by the firms to exert care that goes beyond the legal standard. Such self regulation may also serve to convey to financiers better assurance that a given firm will exert a higher level of care, once the government increases the share of liability falling on financiers as the efficiency of the court system increases.

The second effect implies that the increased efficiency of the court allows the government to increase the liability share of financiers. Two reasons justify this policy choice: first, if the firms behave negligently, the increased efficiency of the courts implies that it become more credible that financiers may be able to partly recover their share of the costs of an environmental accident and second, the government, given the social cost of public funds, wants to avoid costly disbursements by transferring liability from firms to financiers.

From an environmental protection viewpoint, the legislator can transfer more liability to financiers if it can provide a more efficient justice system, thereby protecting financiers against the negligent behaviour of firms: investing in the justice system to increase the efficiency of courts to avoid errors generates benefits for the government both in terms of reductions in accident probabilities and in terms of public money disbursements given that the strict liability of financiers for environmental accidents can be increased.

\section{$\underline{\text { Sensitivity to changes in the profitability of the firm }}^{29}$}

A reduction in the profitability of the firm (higher $\mu$ ) generates a reduced liability for the firm and an increased standard of care; an increase in the probability of suing; a reduction

\footnotetext{
${ }^{28}$ See the discussion of Kaplow (1994) and the others in Section 3 above.

${ }^{29}$ The following sensitivity results are discussed in more details in Boyer and Porrini (2008).
} 
in the level of care and a rise in the probability of accident; and a rise in the probability of conviction. The main factor explaining those results is that a lower profitability of the firm implies a more frequent reliance on government funds to cover the cost of an accident. Hence, to alleviate the effect of the social cost of public funds on the value of SWF, the financier is made increasingly liable, that is, the legal compulsory level of insurance for environmental disasters is increased. Although the level of suing increases, the firm tends to lower its care activities given its reduced liability. The increases in $s$ combined with the reduction in $q$ increases the probability of conviction.

\section{Sensitivity to changes in the cost of care}

A higher cost of care changes the first best values (a reduced care $q$ and therefore an increased probability of accident $p(q)$ ) and generates: a reduced liability for the firm but the standard of care goes up and down; an increase in the probability of suing; a reduction in the level of care; a rise in the probability of accident and in the probability of conviction. The fact that the first best level of care is reduced implies that the government wants to set a lower liability share for the firm inducing a lower level of care and therefore a higher probability of accident.

\section{$\underline{\text { Sensitivity to changes in the efficiency of care }}$}

An increased efficiency of care in reducing the probability of an accident changes the first best values (reduced care level $q$ and a reduced probability of accident $p(q)$ ) and generates: a liability for the firm that goes up and down but a decreased standard of care; a reduction in the probability of suing; a reduction in the level of care but a reduction in the probability of accident; and a reduction in the probability of conviction. When care is more efficient, the government wants to save on costly care activities while achieving a lower probability of accident. To do so, it basically maintains the liability share of the firm but reduces the standard of care; this lowers the value of suing for the financier. Although realised care level and probability of accident move in the same directions as their first best values, the probability of conviction goes down as the reduction in realised care is less pronounced than the reduction in the standard of care. 


\section{Sensitivity to changes in the cost of suing (efficiency of monitoring)}

An increase in the cost of suing generates: an increased liability for the firm and decreased standard of care; a reduction in probability of suing; a reduction in the level of care; an increase in the probability of accident; and, a reduction in the probability of conviction. Clearly, the capacity or efficiency of the financier in inducing proper behaviour by the firm is reduced when the cost of suing increases. Hence, the government will want to impose a higher liability share on the firm. To avoid a too important increase in care activities, it lowers significantly the standard of care leading to a net decrease in the level of care. But again, the reduction in realised care is less pronounced than the reduction in the standard of care and therefore the probability of conviction is lowered.

\section{$\underline{\text { Sensitivity to changes in the social cost of public funds }}$}

An increase in the social cost of public funds (reduced efficiency of government financing) generates: a reduced liability for the firm and increased standard of care; an increase in probability of suing; an early increase and later reduction in care; an early reduction and later increase in probability of accident; and, an increase in the probability of conviction. Those impacts are basically due to the need for the government to reduce its own disbursements given their higher social costs. To achieve that, it lowers the liability share of the firm thereby making the compulsory insurance level higher. To avoid a too important reduction in care, the government increases also the standard of care. This induces the financier to sue more often because of the higher probability of conviction.

\section{CONCLUSION}

A more efficient court system impacts liability sharing and environmental protection through intricate interactions between the factors shaping the incentives faced by firms. A more efficient court system, which contributes to raising the incentives of firms to exert more care, allows the benevolent welfare maximizing government to enact legislation providing a lower legal liability share for the firms as well as a lower standard level of care, expecting that firms and financiers will exploit such legal provisions to reduce the 
probability of suing and to increase the level of care, resulting in the end in a reduced probability of accident. Hence, a more efficient court system allows the stakeholders to face better incentives, allowing for a reduction in the probability of suing and a reduction of the likelihood of costly government disbursements due to a lower liability share for firms, a reduced probability of accident, as well as a reduced overall probability of conviction if an accident case is litigated in courts.

The avenues for further research are both numerous and quite challenging. We considered one channel by which financiers can influence firms' safety strategies. Other channels could be considered, including more general financial contracts and direct involvements of banks and insurers in the design and application of safety strategies.

We considered that care had an impact only on the probability of accidents, not on the loss incurred when an accident occurs. More generally, one could consider a selfprotection care program to reduce the probability of accident and a self-insurance care program to reduce the level of loss if an accident occurs. Moreover, the relative costs of the two programs of care are likely to be different as well as their relative impact on the expected loss. One could consider the relative risk of undertaking those programs because of the existence of different mean preserving spreads between reducing the probability of accidents and reducing the loss those accidents would generate.

Another line of future research would be to consider different court efficiency parameters for errors of Type I and Type II. Again, differential costs of those parameters could be considered in the design of a program to increase court efficiency, with Polinsky and Shavell (2007) and Bisso and Choi (2008) as starting points. Similarly, increased efficiency through reduction of evidentiary uncertainty could be considered, with Fluet (2010) as a starting point. 


\section{REFERENCES}

BACHRACH, G. (ed., 1998), Salvage by the Surety, American Bar Association.

BHOLE, B., (2007), "Due Care Standards in a Market Setting with Legal Error," International Review of Law and Economics 27, 154-169.

BHOLE, B., WAGNER, J. (2008), “The Joint Use of Regulation and Strict Liability with Multidimensional Care and Uncertain Conviction," International Review of Law and Economics 28, 123-132.

BISSO, J.C., CHOI, A.H. (2008), “Optimal Agency Contracts: The Effect of Vicarious Liability and Judicial Error”, International Review of Law and Economics 28(3), 166174.

BOYD, J. (2001), "Financial Assurance Rules and Natural Resource Damage Liability: A Working Marriage?” Resources for the Future Discussion Paper 01-11.

BOYER, M., DIONNE, G. (1983), "Riscophobie et étalement à moyenne constante: Analyse et applications", Actualité économique / Revue d'analyse économique 59(2), 208-229.

BOYER, M., LAFFONT, J.J. (1996), “Environmental Protection, Producer Insolvency and Lender Liability," Chapter 1 in A. Xepapadeas (ed.), Economic Policy for the Environment and Natural Resources, Edward Elgar Pub. Ltd.

BOYER, M., LAFFONT, J.J., MAHENC, P., MOREAUX, M. (1991), “Concurrence Spatiale et Information Incomplète", Revue économique 42(6), 1047-1088.

BOYER, M., LAFFONT, J.J., MAHENC, P., MOREAUX, M. (1994), "Location Distortions under Asymmetric Information”, Regional Science and Urban Economics 24, 409-440.

BOYER, M., LAFFONT, J.J., MAHENC, P., MOREAUX, M. (1995), “Sequential Location Equilibria under Incomplete Information", Economic Theory 6, 323-350.

BOYER M., LAFFONT J.J. (1997), "Environmental Risks and Bank Liability," European Economic Review 41, 1427-1459.

BOYER M., LEWIS, T.R., LIU, W.L. (2000), "Setting Standards for Credible Compliance and Law Enforcement," Canadian Journal of Economics 33(2), 319-340.

BOYER, M., PORRINI, D. (2001), “Law versus Regulation: A Political Economy Model of Instruments Choice in Environmental Policy," in A. HEYES (ed.), Law and Economics of the Environment, Edward Elgar Publishing Ltd.

BOYER, M., PORRINI, D. (2004), "Modelling the Choice between Regulation and Liability in Terms of Social Welfare," Canadian Journal of Economics 37(3), 590-612.

BOYER, M., PORRINI, D. (2006), "Sharing Liability between Banks and Firms: The Case of Industrial Safety Risk," chap. 13 in M. Boyer, Y. Hiriart and D. Martimort (eds.), Frontiers in the Economics of Environmental Regulation and Liability, Ashgate Pub. 
BOYER, M., PORRINI, D. (2008), "The Efficient Liability Sharing Factor for Environmental Disasters: Lessons for Optimal Insurance Regulation," Geneva Papers on Risk and Insurance: Issues and Practice 33, 337-362.

BURROWS, P. (1999), "Combining Regulation and Legal Liability for the Control of External Costs," International Review of Law and Economics 19, 227-244.

CALABRESI, G. (1970), The Cost of Accident, Yale University Press, New Haven.

DAUGHETY, A.F., REINGANUM, J.F. (2006), "Markets, Torts and Social Inefficiency," RAND Journal of Economics 37(2), 300-323.

DARI-MATTIACCI, G., DE GEEST, G. (2005), "Judgment Proofness under Four Different Precaution Technologies," Journal of Institutional and Theoretical Economics 161(1), 38-56.

DE GEEST, G., DARI-MATTIACCI, G. (2007), "Soft Regulators, Tough Judges," Supreme Court Economic Review 15, 119-140

DEMOUGIN, D., FLUET, C. (2008), "Rules of Proof, Courts, and Incentives," RAND Journal of Economics 39(1), 20-40.

FLUET, C. (2010), "Liability Rules Under Evidentiary Uncertainty,” International Review of Law and Economics 30, 1-9.

GRACER, J., LEAS, C. (2008), "Lender Beware: Navigating the Superfund Safe Harbour During Workouts and Foreclosures," New York Law Journal, July 14.

HUTCHINSON, E., VAN'T VELD, K. (2005), "Extended Liability for Environmental Accidents: What You See is What You Get," Journal of Environmental Economics and Management 49, 157-173

INNES, R. (2004), "Enforcement Costs, Optimal Sanctions, and The Choice Between Ex Post Liability and Ex Ante Regulation", International Review of Law and Economics 24, $29-48$.

KAPLOW L. (1994), "The Value of Accuracy in Adjudication: An Economic Analysis," Journal of Legal Studies 23 (1), 307-401.

KOLSTAD, C. D., ULEN, T. S., JOHNSON, G. V. (1990), "Ex Post Liability For Harm Versus Ex Ante Safety Regulation: Substitutes or Complements?” American Economic Review 80, 888-901.

LAFFONT, J.J., MARTIMORT, D. (2001), The Theory of Incentives: The PrincipalAgent Model, Princeton University Press, Princeton.

LANDEO, C.M., NIKITIN, M., BAKER, S. (2007), "Deterrence, Lawsuits, and Litigation Outcomes under Court Errors," Journal of Law, Economics, and Organization 23, 57-97.

MARCO, A.C. (2006), "Learning by Suing: Structural Estimates of Court Errors in Patent Litigation," Vassar College Economics Working Paper 68.

PNG, I.P.L. (1987), "Litigation, Liability, and the Incentives for Care," Journal of Public Economics 34, 61-85. 
POLINSKY, A.M. (2003), "Principal-Agent Liability," in Introduction to Law and Economics, Third Edition, chapter 3, Kluwer.

POLINSKY, A.M., SHAVELL S. (2007), "The Theory of Public Enforcement of Law," in A.M. Polinsky and S. Shavell (eds.), Handbook of Law and Economics, Amsterdam: Elsevier.

RINGLEB, A.H., WIGGINS, N. (1990), "Liability and Large-Scale, Long-Term Hazards," Journal of Political Economy 98, 574-595.

ROTHSCHILD, M., STIGLITZ, J.E. (1970), “Increasing Risk II: Its Economic Consequences," Journal of Economic Theory 3, 66-84.

SCHMITZ, P.W. (2000), "On The Joint Use of Liability and Safety Regulation," International Review of Law and Economics 20, 371-382.

SHAVELL, S. (1982), “On Liability and Insurance,” Bell Journal of Economics 3, 120132.

SHAVELL, S. (1984), "A Model of the Optimal Use of Liability and Safety Regulation," RAND Journal of Economics 15, 271-280.

SHAVELL, S. (1986), “The Judgment Proof Problem," International Review of Law and Economics 6, 45-58.

SHAVELL, S. (1987), Economic Analysis of Accident Law, Harvard University Press, Cambridge, MA.

SHLEIFER, A. (2010), “Efficient Regulation”, NBER Working Paper No. 15651, January

TREBILCOCK, M., WINTER, R.A. (1997), “The Economics of Nuclear Accident Law,” International Review of Law and Economics 17, 215-243.

TULLOCK, G. (1980), Trials on Trial: The Pure Theory of Legal Procedure, Columbia University Press, New York, NY.

TULLOCK, G. (1994), “Court Errors,” European Journal of Law and Economics 1, 921. 